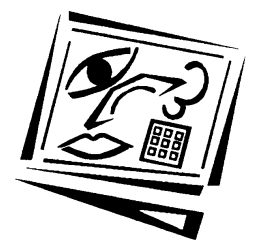

\title{
Learners' access to tools and experience with technology at the University of the South Pacific: Readiness for e-learning
}

\author{
Shikha Raturi, Robert Hogan and Konai Helu Thaman \\ University of the South Pacific
}

\begin{abstract}
Technology in higher education has become exceedingly popular and useful; however, a digital divide generally applies to the use of technology in education in many developing countries. The Pacific Island countries differ in their technological capacities and infrastructure, with the Fijian capital Suva being most technologically and infrastructurally advanced compared with other towns in Fiji and in other Pacific Island countries. This led the researchers to investigate access to e-learning tools and experience with technology amongst a group of 92 students, ranging from 18 to over 55 years of age, enrolled in postgraduate courses in education at the University of the South Pacific. A survey consisting of questions on age, gender, qualification, professional experience, ethnicity and access to and experience with technology was carried out for one cohort. The findings indicate an encouraging level of readiness for e-learning.
\end{abstract}

\section{Introduction}

The Pacific Island countries are sparsely populated and spread across the Pacific Ocean. In order to make education accessible to masses, it would be worth probing if Pacific Islanders have adequate access to and experience with technology, should the alternative methods of instructional delivery in distance education be provided on a larger scale. The University of the South Pacific (USP) is a regional university in the South Pacific region and serves its twelve member countries (Cook Islands, Fiji, Kiribati, Marshall Islands, Nauru, Niue, Samoa, Solomon Islands, Tokelau, Tonga, Tuvalu and Vanuatu) having a total population of approximately 1.4 million, extending over 33 million square kilometres of ocean. USP also attracts students from other Pacific Island countries in the region besides the member countries. Distance education (DE) in print mode started with six courses in 1971 and grew to 340 courses in 2006. Sharma (2008) highlights the basic role played by information and communication technologies (ICTs) in DE through print mode.

Although DE at USP has undergone an exponential growth (Baba, 1997; Sharma, 2008), it has encountered unique challenges (Prasad, 1988; Tuimaleali'ifano, 1994; Hola, 1995; Bolabola \& Wah, 1995; Thaman, 2001; Marsh \& Hogan, 2005; Sharma, 2008). In order to propose and implement modifications in the existing education policy and practices designed to curb these problems, an empirical study of student background is warranted. There has been a tremendous transformation in DE leading up to the fourth generation of the flexible learning model (Taylor, 1995), giving educational institutions a number of options to improve or modify the curricula, necessary ICTs 
and pedagogical practices. It is, therefore, important to gauge the learners' access and experience with basic tools and technology in order to determine the digital status of the learner.

\section{Background and context}

Prensky (2001) coined the terms digital natives and digital immigrants to identify two sets of technology users which can perhaps be used as a starting point. Digital natives refers to students who are 'native language' speakers of the digital language of computers, video games and the internet (Prensky, 2001). Digital immigrants refers to those who were not born with technology around them but became fascinated and adopted the digital language/ technology in the later stages of their lives (Prensky, 2001). Prensky's terms have been debated in light of the complex relationship between technology and learners, the so-called digital natives and digital immigrants, and the lack of empirical research as a basis for the generalisations (Bennett, Maton \& Kervin, 2008; Kennedy, Judd, Churchward, Gray \& Krause, 2008; Oliver \& Goerke, 2007). In the South Pacific and in particular the smaller Pacific Island countries, the technology scene varies as compared to the developed world, with the exception of a few technology enthusiasts who can challenge technocrats from the developed world. This digital disparity requires investigation. In the early $70 \mathrm{~s}, \mathrm{DE}$ in print mode was seen as a plausible solution by USP for making education accessible to learners in the small islands of the region. But the smallness of islands, geographical fragmentation, accessibility and flexibility of DE, the changing demographic, technology, etc., pose serious challenges and problems for a print-based DE program in the region.

The problems ranged from ineffective communication leading to isolation (Thaman, 2001), little or no guidance and mentoring of students reflecting in their organisational behaviour (Chief \& Hola, 1995), course structure and turnaround time for assignments leading to high dropout rates (Prasad, 1988), low success rates (Lal, 1989) and gender specific struggles (Tuimaleali'ifano, 1994; Bolabola \& Wah, 1995). On the other hand, Baba (1997) highlighted the crucial issue of addressing the need for human resource development considering the migration of skilled individuals from Fiji every year.

It was also felt that the integration of technology and training in schools and higher education (Hammond, 2000; Thaman, 2001; Nabobo-Baba, 2002; Bakalevu, 2005; Johansan-Fua, 2005; Puamau, 2005; Whelan, 2007; Sharma, 2008) was important to improve the accessibility (Marsh \& Hogan, 2005) and quality of DE which is very important for the Pacific Islands (Thaman, 2001). ICTs have been basic to the USP's print-based DE since 1971 and has made substantial progress (Sharma, 2008). The use of audio conferencing, email, telephone and fax between the main hub in Suva and other campuses and centres was possible as a result of establishment of USPNet in 1973 and its subsequent evolution (ADB, 2007). Johanson-Fua (2005) highlighted the PRIDE (Pacific Regional Initiatives for the Delivery of Basic Education) projects' role by member countries in developing their curriculum in ICTs and ICT related professional development for teachers. On the whole ICTs have improved in Fiji and its campuses and centres, technology such as Pnet in Solomon Islands, EduNet in Cook Islands, and AARNet connection has also improved the system further in Pacific Island countries (Bakalevu, 2005; Sharma, 2008).

In his attempt to discuss ICT in education and teacher training, Sharma (2008) referred to the importance of three different learning and teaching styles in ICT-driven 
technology, including a 'blended' or 'hybrid' mode and 'fully online' specifically for distance education as well as for professional development programs for teachers along with the traditional face to face courses. On the other hand, contrary to the prevailing belief, Marsh and Hogan (2005) suggested online learning as a useful tool for all South Pacific learners. In the light of literature pertaining to challenges and problems with current print-based DE and suggestions regarding modification to pedagogical practices, it would be necessary to gauge access to and experience with tools and technology amongst the learners.

\section{Technological advances relevant for this study: Tools and online resources}

The life of a learner/ student now is definitely far more comfortable than in the preInternet era. The Internet then gave rise to the possibility of a whole new range of online resources. The use of email has been maximised in the online education system. With the advent of technology, there are now an increasing number of companies and organisations (for example, http://www.merlot.com/; http://www.virtlab.com/) that provide a variety of online learning and teaching tools to enhance different types of interactions. Websites such as Merlot and Virtlab offer lecture notes, quizzes, simulations and other study materials. While Merlot is open to all subjects, Virtlab is currently limited in offering teaching and learning resources in Chemistry, though both offer free services. One can contribute to the database in resources in Merlot and it encourages a healthy exchange of ideas in academic fraternity. Weblogs or blogs (an example of such a blog can be accessed from http:/ / www.deincanada.blogspot.com/) in education, are yet another means of interaction focusing on socio-cultural, cognitive and academic presences. However, the pros and cons of using these kinds of resources have been debated (Cameron \& Anderson, 2006). Some of the online applications are termed as 'killer apps' (email, Skype are some of those referred to as killer applications) for the simple reason of their very widespread adoption.

One of the most popular tools was the development of learning management systems (LMS) software which enabled online delivery, tracking and managing of training or education of any form with ease. Tong (2004) defines the LMS as a web-based system that provides tools to create and deliver online materials to facilitate interaction with students through discussion forums, emails, monitoring student participation and assessing their performance by means of online quizzes, exams and online submission of assignments. The availability and use of this technology has transformed the education scenario in many universities and schools. Blackboard, WebCT, Moodle, etc, are some of the learning management systems. Moodle being a free software is adopted by many universities in developing countries. The universities make use of these LMS to communicate learning resources to the learners. In the University of South Pacific (USP), academics and students have used Class Shares which is a space on the USP network where lecturers can place files with information related to a particular course, to enable student access. These files commonly contain lecture notes in any form (e.g. MS Word, PowerPoint presentation), tutorials, past test papers, notices, syllabus, etc. It used to be a common mode of one way communication from lecturer to students. Due to the very nature of 'one way' communication mode, Class Shares is being phased out by the growing use of Moodle course pages at USP. The variety of online resources that can be communicated to and fro (lecturer to student and vice versa, and studentstudent) through Moodle far outweighs the capabilities of Class Shares. 
Online resources are slowly and steadily working towards resolving a number of developmental issues in education. Thus, the use of technology has added a whole new dimension to the field of education; educators are beginning to realise the full potential of technology as a medium to offer knowledge to students at a distance, not via the traditional print based system but online. It is therefore, extremely important to gauge the digital status of learners in South Pacific region. This study looked at the technology background of learners by investigating access to tools and technology as well as their experience with it.

\section{Technology background}

Technology background concentrates on access to tools and technology and experience with computer and Internet applications. A sound technology background would make an individual comfortable and confident with any instructional delivery mode and not having a 'fear' for it (Shank, 2005), though some studies suggests this is insignificant (Shehab, 2007). However, in this day and age where technology has transformed education scene, it was worth investigating the current status of access to tools and technology and experience with some computer and Internet applications. An investigation into the technology backgrounds of learners or faculty has not been attempted in the USP context for Pacific Island countries, unlike universities in Australia, for example (Burnip, 2006; Oliver \& Goerke, 2007; Kennedy et al, 2008). The author felt that a baseline investigation study with a small sample would provide a necessary foundation for further studies in this field.

\section{Access to tools and technology}

The tools and technology refer to mobile phone, computer and Internet connection. 'One laptop per child' (OLPC - http://www.laptop.org/) is an education project to empower the children of developing countries to learn by providing one connected laptop to every school-age child. For example the project has helped to transform the lives of children and their families in a remote Cambodian village (Negroponte, 2002). OLPC has also been implemented in some of the Pacific Island countries such as Solomon Islands (ACER Report, 2010) and has done reasonably well. An easy access to a fast Internet connection to download a Word document or a PowerPoint or an audio/video file in few seconds to few minutes may influence the individual's experience with the process. Burnip (2006) pointed out the problem that can arise through limited access to technical support, especially if there are variable levels of skills amongst the learners. Similarly, differences in technical background may pose a challenge for effective team work among learners in a virtual learning environment (He, Wang \& Li, 2008). However, the bottom line is that the use of tools and technology effectively enhances the learning process (Amber, 2008) and this needs to be taken into consideration to make organizational changes in pedagogical practices. But considering the differences in the infrastructure of the Pacific Island countries, it was worthwhile to investigate if this would have any bearing on access to tools and technology amongst learners in this study group.

\section{Experience with technology}

Computer applications

In this study, familiarity with computer applications such as word processing, spreadsheets, Paint and Publisher was investigated. These simple applications are used frequently by learners, teachers and professional nowadays and some of the 
applications are used in a traditional classroom too. Experience with computer applications would be an essential factor if an individual would like to utilise virtual learning environments and therefore it could influence their preference towards the instructional delivery mode.

\section{Internet applications}

Similarly amongst the Internet applications, familiarity with email, Class Shares, LMS, online library searches, search engines (Yahoo, Google, etc.), online services (payment of fees, registration, etc.), social networking sites (Facebook, Bebo, Twitter, etc.) instant messaging (Yahoo Messenger, Gtalk, Skype, etc.) and blogs were investigated. The applications chosen in this case are the simple ones that are used commonly in this region. Class Shares is a USP specific LMS and it is used by the students and faculty of USP throughout the region along with Moodle. Considering the current changing educational scene, experience with this group of Internet applications or willingness to learn is essential in order to study a course offered through virtual learning environment (especially in future).

However, considering the different technological capacity of Pacific Island countries, it was worthwhile studying the experience with technology amongst the cohort. Another aspect of the study was to investigate the relationship between different variables, if any.

\section{Method}

The survey questionnaire looked at the quantitative aspect by providing descriptive statistics on population distribution and general trends.

\section{Sample}

In order to gauge the digital status of learners, a case study at USP was carried out. Three groups of graduate level students selected for the study experienced three different instructional delivery modes. These courses are either part of the postgraduate certificate, diploma or degree programs for education professionals. The courses were labeled as EDf2f (Education courses via face to face mode), EDBlen (Education course via blended mode) and EDElearn (Education course via e-learning mode); 'f2f', 'Blen' and 'Elearn' denoting the mode of instructional delivery. While some learners were at a fairly early stage of their academic and professional careers, others were far more experienced with some retirees enrolled once again to professionally develop themselves. EDBlen is offered as part of the Graduate Certificate in Tertiary Teaching (GCTT); all three courses can be taken as part of a Post Graduate Diploma in Education (PGDE) or a Masters program (MEd).

\section{Instrument}

The instrument consisted of three groups of questions aimed at learners' background, technology background and application experience. The first group on background details consisted of seven items focused on qualification, profession, gender, age, ethnicity, etc. The second group on technology background consisted of six items to evaluate access to technology and focused on access to computer, internet and mobile (table 3 ). The third group on experience with computer and Internet applications consisted of twelve items and focused on various simple applications needed for educational technology purposes (Table 4). A rating of 1-5 with 1 being least and 5 
being highest was used to self assess the access and experience with tools and technology. Two versions of questionnaire were created, a 'computer version' to be completed online and another one 'print based' to cater for f $2 \mathrm{f}$ students mainly if they preferred to fill in by hand.

\section{Procedure}

The course coordinators were contacted for permissions and the data was collected during week 10-15 in semester II (October-November, 2009). The participants were asked to fill in the questionnaire either online or in print depending on their preference. All the questionnaires in print were completed in 15 minutes during the lecture time (the lecturer agreed to give 15 minutes of time for researcher to be with the class) making it easy for the researcher to collect $100 \%$ completed questionnaires. Reminders were sent through email in order to ensure the return of online completed questionnaires. It was also interesting to note that out of 92 students, 35 completed the printed version while 58 completed the questionnaire online.

\section{Results}

The data was analysed using PASW Statistics18 (formerly SPSS Statistics) and appropriate statistical tests that best interpreted the data to address the research questions. The results are shown with the help of the figures and tables depending on what described the demographics the best. Correlations between learners' background (demographic factors), access to technology and experience with technology was also investigated.

\section{Learners' background}

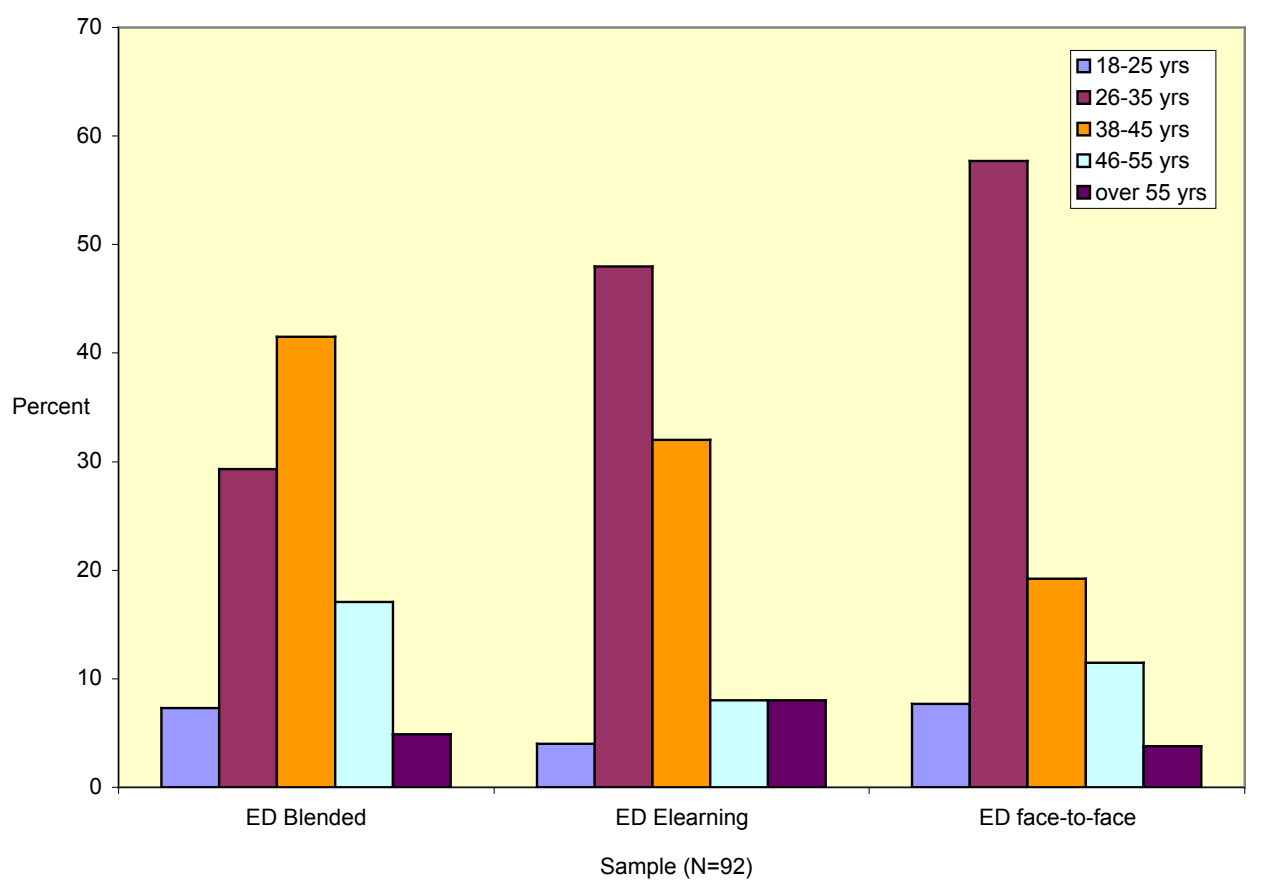

Figure 1: Distribution of age $(\mathrm{N}=92)$ 


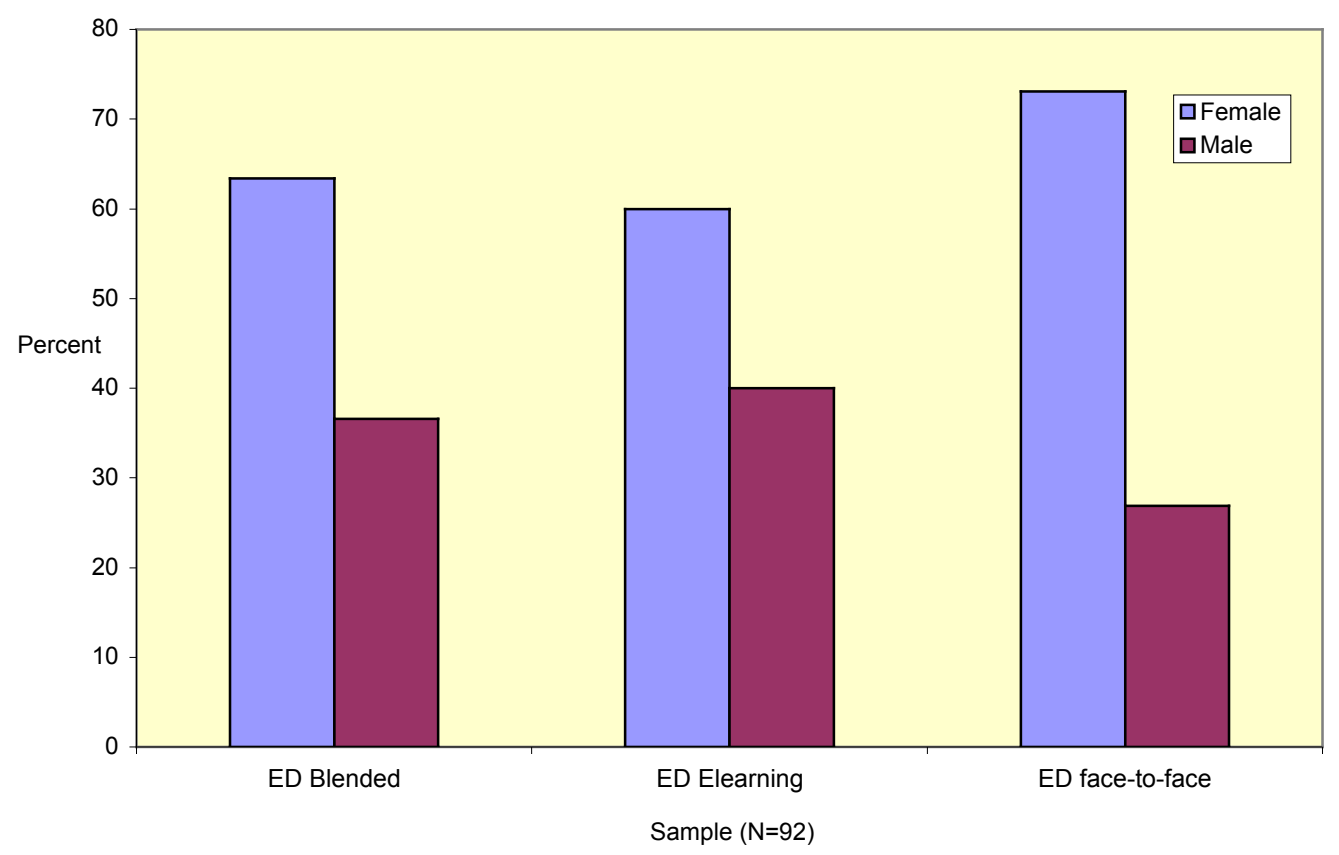

Figure 2: Distribution of gender $(\mathrm{N}=92)$

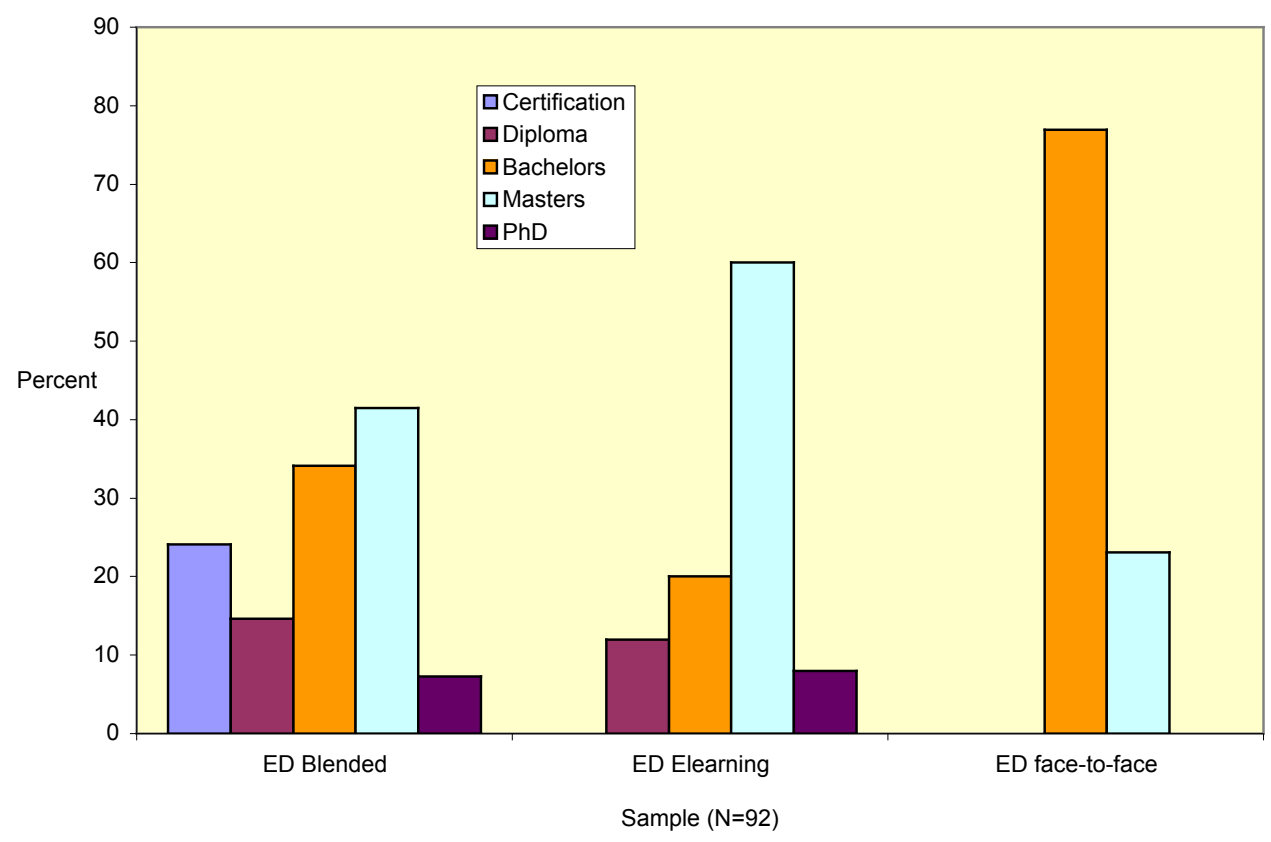

Figure 3: Distribution of academic level (N=92) 


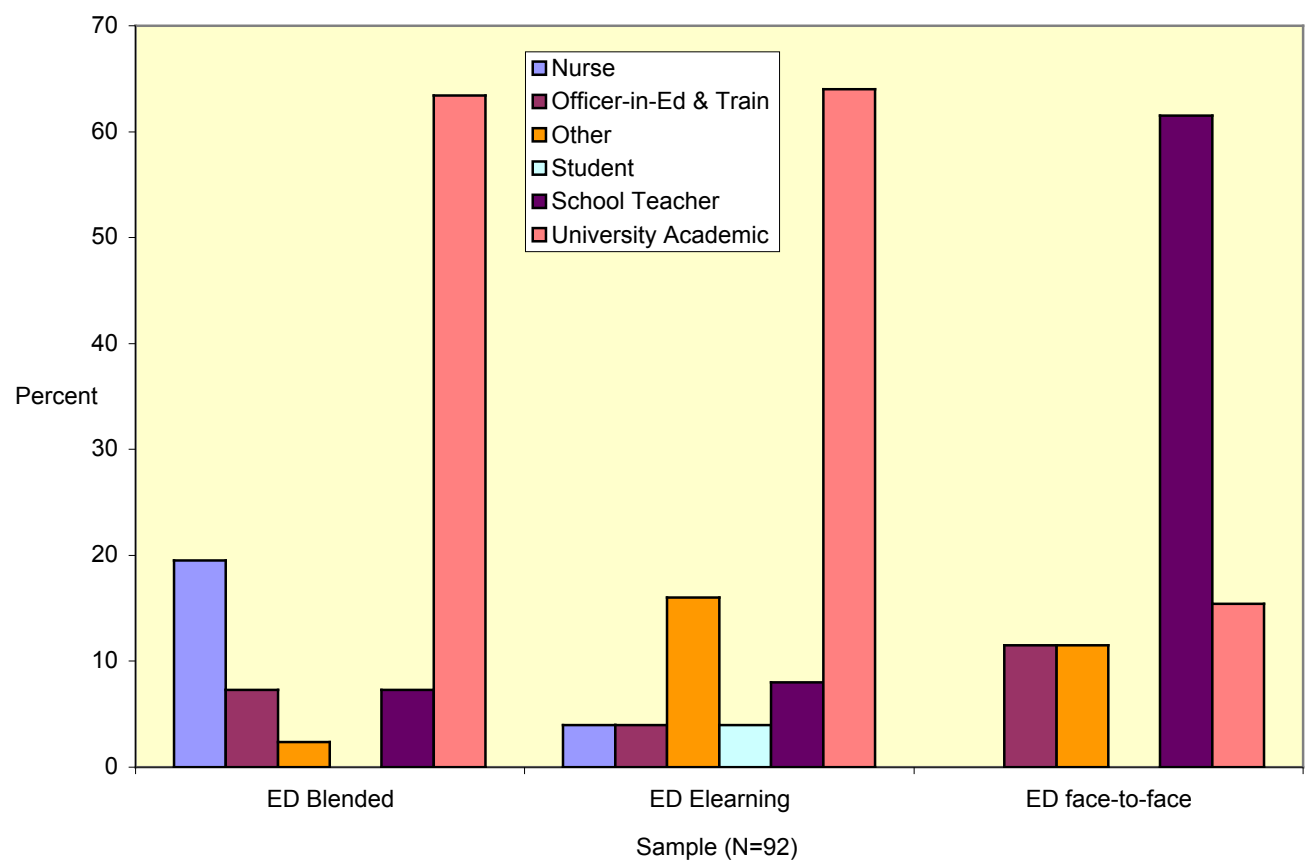

Figure 4: Distribution of profession $(\mathrm{N}=92)$

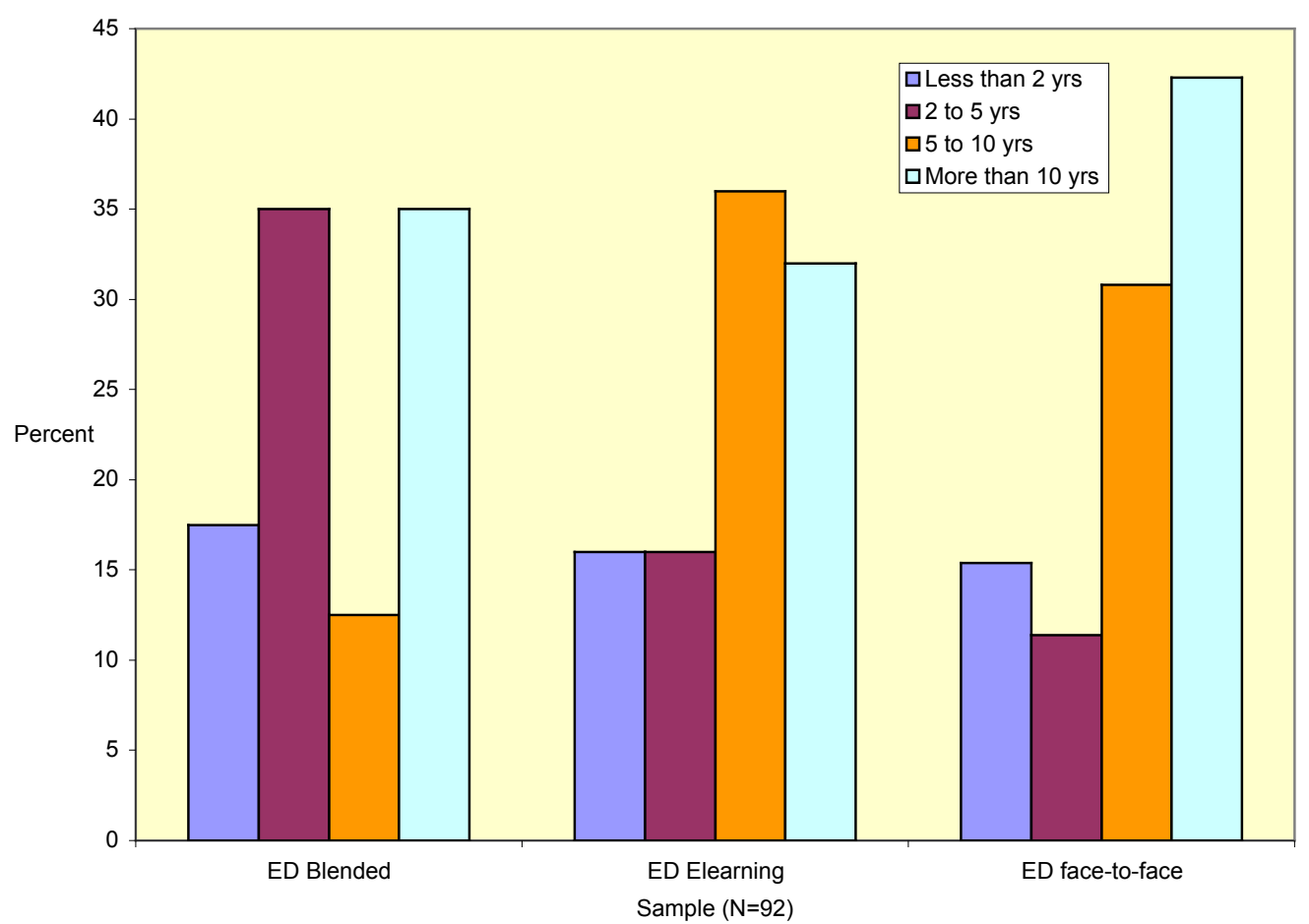

Figure 5: Distribution of professional experience $(\mathrm{N}=92)$ 
Table 1: Distribution of ethnicity

(cross-tabulation with all values in \%; actual numbers in brackets)

\begin{tabular}{|c|c|c|c|c|c|c|c|c|c|c|}
\hline \multirow{2}{*}{ Ethnicity } & \multicolumn{3}{|c|}{ EDBlended } & \multicolumn{3}{|c|}{ EDElearning } & \multicolumn{3}{|c|}{ EDf2f } & \multirow{2}{*}{\begin{tabular}{|c} 
Total \\
$\begin{array}{c}\% \text { within } \\
\text { sample }\end{array}$
\end{tabular}} \\
\hline & \begin{tabular}{|c|}
$\%$ within \\
sample
\end{tabular} & $\begin{array}{l}\% \text { within } \\
\text { ethnicity }\end{array}$ & $\begin{array}{l}\% \text { of } \\
\text { Total }\end{array}$ & $\begin{array}{c}\% \text { within } \\
\text { sample }\end{array}$ & $\begin{array}{l}\% \text { within } \\
\text { ethnicity }\end{array}$ & $\begin{array}{l}\% \text { of } \\
\text { Total }\end{array}$ & $\begin{array}{c}\% \text { within } \\
\text { sample }\end{array}$ & $\begin{array}{l}\% \text { within } \\
\text { ethnicity }\end{array}$ & $\begin{array}{l}\% \text { of } \\
\text { Total }\end{array}$ & \\
\hline Caucasian & & & & $16.0(4)$ & 66.7 & 4.3 & $7.7(7)$ & 33.3 & 2.2 & $6.5(6)$ \\
\hline Fijian & $41.5(17)$ & 63.0 & 18.5 & $8.0(2)$ & 7.4 & 2.2 & $30.8(8)$ & 29.6 & 8.7 & $29.3(27)$ \\
\hline Filipino & & & & $4.0(1)$ & 100.0 & 1.1 & & & & $1.1(1)$ \\
\hline Indian & $51.2(21)$ & 55.3 & 22.8 & $32.0(8)$ & 21.1 & 8.7 & $34.6(9)$ & 23.7 & 9.8 & $41.3(38)$ \\
\hline Micronesian & & & & $28.0(7)$ & 100.0 & 7.6 & & & & $7.6(7)$ \\
\hline Niue-Vanuatu & $2.4(1)$ & 100.0 & 1.1 & & & & & & & $1.1(1)$ \\
\hline Others & $2.4(1)$ & 20.0 & 1.1 & $4.0(1)$ & 20.0 & 1.1 & $11.5(3)$ & 60.0 & 3.3 & $5.4(5)$ \\
\hline Pacific Islander & $2.4(1)$ & 50.0 & 1.1 & $4.0(1)$ & 50.0 & 1.1 & & & & $2.2(2)$ \\
\hline Rotuman & & & & & & & $3.8(1)$ & 100.0 & 1.1 & $1.1(1)$ \\
\hline Solomon Islander & & & & & & & $11.5(3)$ & 100.0 & 3.3 & $3.3(3)$ \\
\hline Vietnamese & & & & $4.0(1)$ & 100.0 & 1.1 & & & & $1.1(1)$ \\
\hline Total & $100(41)$ & 44.6 & 44.6 & $100(25)$ & 27.2 & 27.2 & $100(26)$ & 28.3 & 28.3 & $100(92)$ \\
\hline
\end{tabular}

\section{Access to technology}

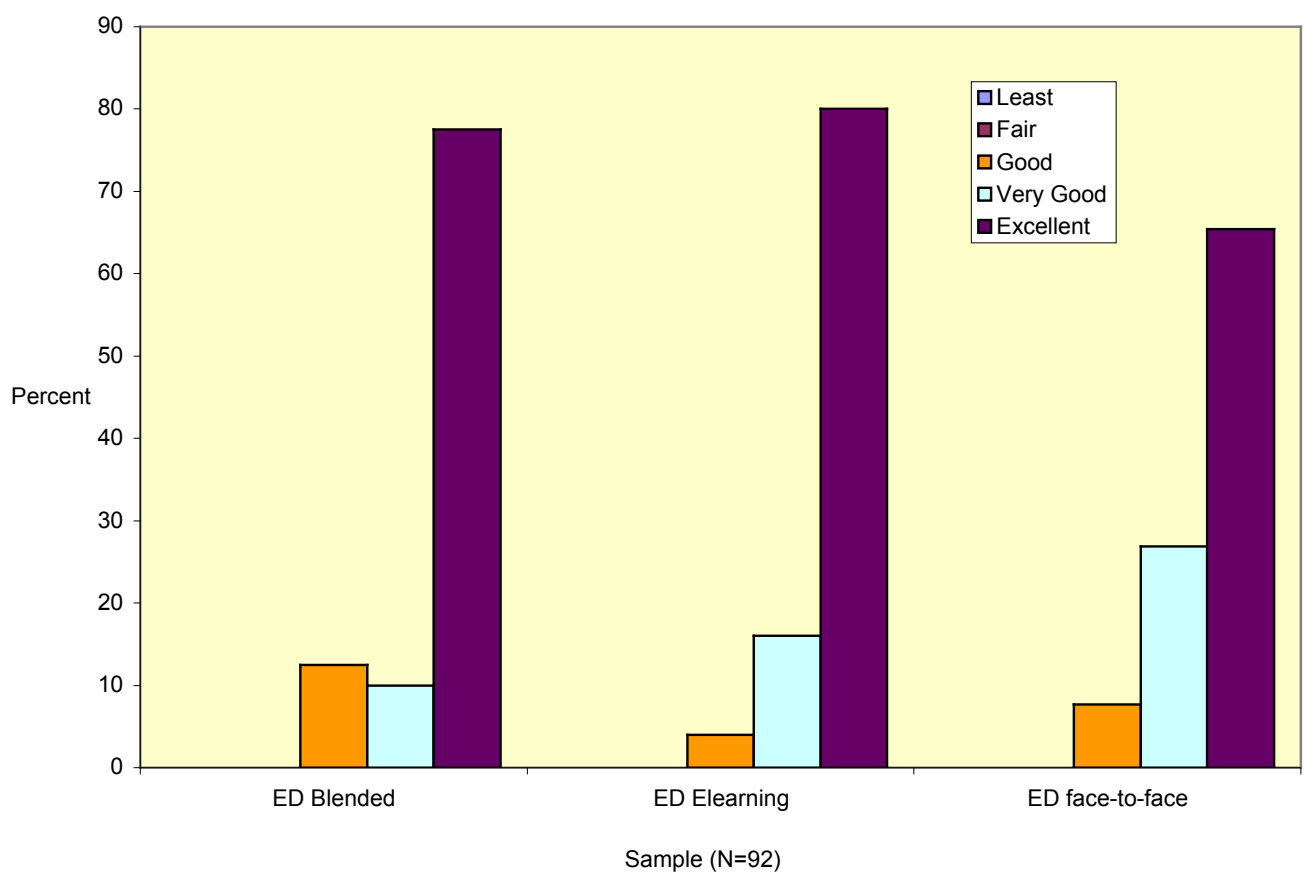

Figure 6: Distribution of access to technology $(\mathrm{N}=92)$ 


\section{Experience with technology (computer and Internet applications)}

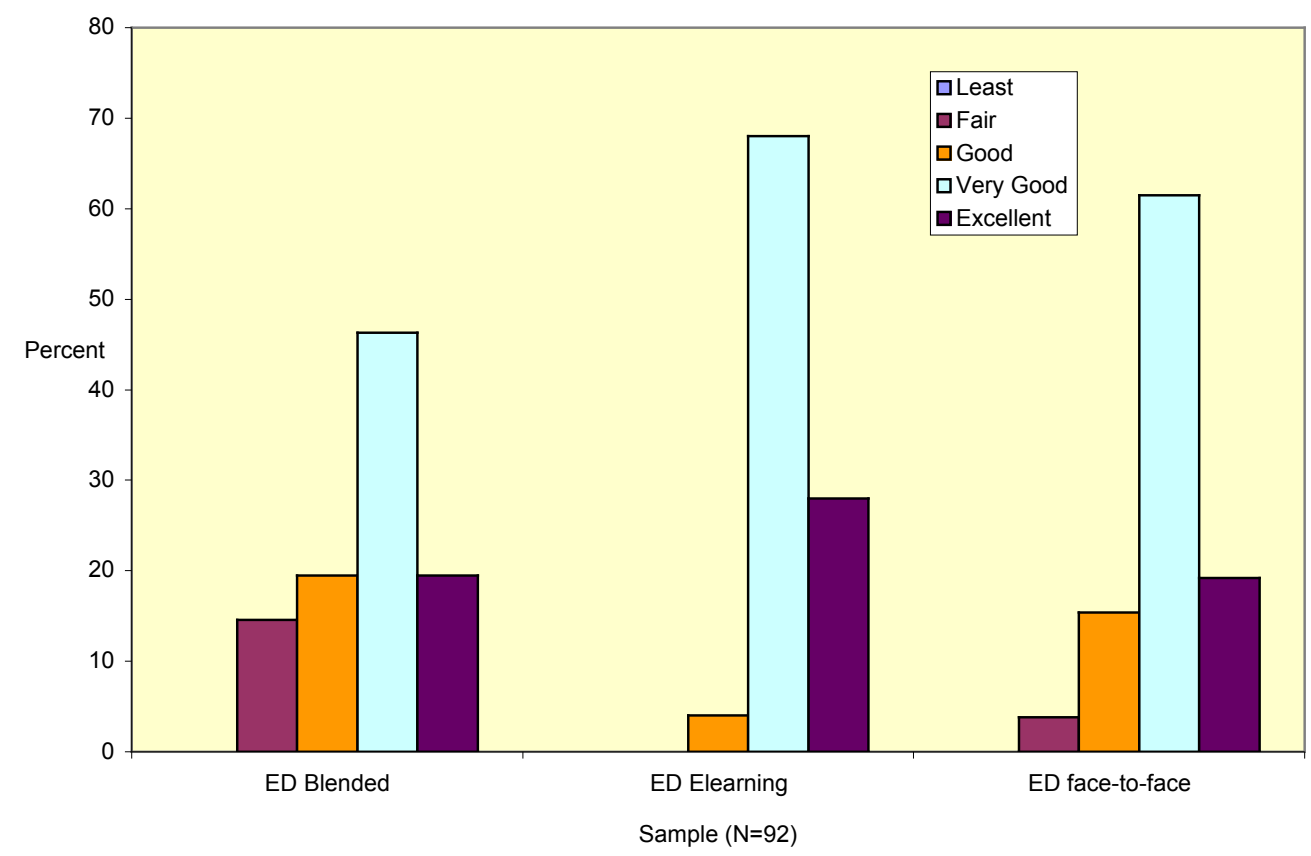

Figure 7: Distribution of experience with technology $(\mathrm{N}=92)$

\section{Some relationships}

The correlation studies were carried out by non-parametric tests. Spearman's rho and the results for the significant relationships are shown in Table 2

Table 2: Relationship between technology experience, tools and technology and academic level

\begin{tabular}{|l|l|c|c|}
\hline \multicolumn{2}{|c|}{} & $\begin{array}{c}\text { Access to tools } \\
\text { and technology }\end{array}$ & $\begin{array}{c}\text { Academic } \\
\text { level }\end{array}$ \\
\hline $\begin{array}{l}\text { Technology } \\
\text { experience }\end{array}$ & Rho & $.259^{*}$ & $.271^{* *}$ \\
\cline { 2 - 4 } & Sig. (2-tailed) & .013 & .009 \\
\cline { 2 - 4 } & $\mathrm{N}$ & 91 & 92 \\
\hline
\end{tabular}

* Correlation is significant at the 0.05 level (2-tailed)

${ }^{* *}$ Correlation is significant at the 0.01 level (2-tailed)

There is a significant correlation among some of the variables; access to tools and technology has a positive relationship with technology experience at 0.05 level while academic level shows a positive relationship with technology experience at 0.01 level.

\section{Discussion and implications}

In each of the three groups, the majority of the learners are from the age group 26-45 years with $70-80 \%$ on average (Figure 1) and females dominated each group with 60$70 \%$ on average (Figure 2). It was interesting to note that the course with least technology support was dominated by the age group 26-35 years (40\%) followed by 
36-45 years (30\%) for the courses using technology (blended and e-learning). This indicates that technology is not an issue amongst the learners in the age group 36-45 years, instead they along with others seemed comfortable with the use of technology.

The majority of the learners have a bachelor and/or masters degree on an average of $70-100 \%$ (Figure 3) and the majority of the learners are experienced professionals (mainly university academic and teachers as indicated by Figure 4, though school teachers make up the majority of learners in EDf2f). The learners' experience was mainly between 5-10 yrs to $>10$ years except for learners in blended mode where the learners mainly had experience in the range of $2-5 \mathrm{yrs}$ and $>10 \mathrm{yrs}$ (Figure 5). The academic level, profession and professional experience of this cohort implies that they might have reasonable access to technology (especially at work). Since experience with technology depends on individuals' interest and motivation to use it, therefore, access to technology cannot guarantee their experience with it.

This sample was a diverse group with learners from major Pacific Island countries, with majority of learners being Indo-Fijians and Fijians, there were other ethnic learners (Caucasian/ European and Asian heritage). The demographic of this cohort was a reasonable spread of variety of ethnicity from different parts of the world. It also indicates that female population in this sample must have the necessary technology skills considering they are enrolled in courses utilising technology for instruction. The correlation studies also indicate that gender did not affect their access and experience with technology.

In short, the demographic data reveals that education courses are taken by students from diverse backgrounds in terms of age, ethnicity, gender, academic level and professional experience. The need for education courses will grow and on the basis of previous trends of increased enrollments in distance education and traditional education in the region, it will continue to increase. The fact that majority of learners are working also hints at the need for flexibility in course delivery. It becomes imperative that the learners are equipped with the necessary tools and technology experience, so, are they?

Table 3: Part of questionnaire on access to technology

\begin{tabular}{|lllll|}
\hline How long have you used computers?: & $<2 \mathrm{yrs}$ & $2-5 \mathrm{yrs}$ & $5-10 \mathrm{yrs}$ & $>10 \mathrm{yrs}$ \\
How long have you used Internet: & $<2 \mathrm{yrs}$ & $2-5 \mathrm{yrs}$ & $5-10 \mathrm{yrs}$ & $>10 \mathrm{yrs}$ \\
I have a computer at home: YES $\quad$ NO & at work: YES & NO \\
I have Internet access at home: YES NO N & at work: YES NO \\
Internet connection (check all that apply) Broadband & Dialup & Wireless \\
I have a mobile phone: YES NO N & &
\end{tabular}

Overall of $75 \%$ of the learners considered that the access to technology as shown in Table 3 was at an excellent level for them with nil reporting it to be less than average. It is not surprising that only one student did not have a mobile phone. What was even more important was that not having a mobile was for this individual more of a personal choice than rather than accessibility or not being able to afford it (personal communication). It was interesting to note that learners in EDBlen (responses 77.5\% excellent, $10 \%$ very good and $12.5 \%$ good), EDElearn (responses were $80 \%$ excellent, $16 \%$ very good and $4 \%$ good) and EDf2f (responses were $65.4 \%$ excellent, $26.9 \%$ very good and $7.7 \%$ good) had similar technology access and demographic background. As 
discussed and assumed earlier, the result also suggests that the access to technology was more than adequate.

Table 4: Part of questionnaire on experience with technology

\begin{tabular}{|l|l|l|l|l|l|}
\hline \multicolumn{1}{|c|}{ Rate your level of proficiency with: } & 1 & 2 & 3 & 4 & 5 \\
\hline Word processing & & & & & \\
\hline Spreadsheets & & & & & \\
\hline Paint, Publisher, etc & & & & & \\
\hline Email & & & & & \\
\hline Class Shares & & & & \\
\hline Moodle, Nicenet, WebCT or other LMS & & & & & \\
\hline Online library searches & & & \\
\hline Search engines e.g. Google, Yahoo, online dictionary, etc. & & & \\
\hline Online services e.g. registration, pay fees, etc. & & & & \\
\hline Bebo, Facebook, Twitter, etc. & & & & \\
\hline Yahoo Messenger, MSN, Gtalk, Skype, etc. & & & & & \\
\hline Blogs & & & & & \\
\hline Note: 1 = Least; 2 Fair; 3 = Good; 4 Very good; 5 = Excellent & & &
\end{tabular}

Similarly, the experience with computer and Internet applications (as stated in Table 4) was between 'very good' and 'excellent' for about $78 \%$ of the learners in different courses, it was noteworthy that learners enrolled for EDf2f were amongst the second highest in the three courses. The responses from EDBlen (responses 19.5\% excellent, $46.3 \%$ very good and $19.5 \%$ good), EDElearn (responses $28 \%$ excellent, $68 \%$ very good and $4 \%$ good) and EDf2f (responses 19.2\% excellent, 61.5\% very good and $15.4 \%$ good) proved that the learners had the necessary 'know how' if they chose to do a certain course though e-learning instructional delivery mode.

Technology access had an effect on the technology experience as indicated by learners which was proven by a small positive relationship $(\mathrm{rho}=.259)$ at .05 level (2-tailed) as indicated in Table 2. However, one point that emerges quite clear from this demographic study for this sample is that this is not a digital generation but a group of technology enthusiasts who have embraced technology for various reasons, these individuals have adapted to the technology and they fit well in the current technological world. Thus, this group of individuals can be considered as digital immigrants (Prensky, 2001) or 'digital adapters' - the term we would like to use for this cohort and such learners in other parts of the world.

Digital immigrant versus digital adapter

The author prefers to use the term adapter over immigrant and address the 'digital immigrants' as 'digital adapters'. Prensky (2001) proposed the term immigrant as the direct opposite of native. Prensky says "...the most useful designation I have found for them is Digital Natives. Our students today are all "native speakers" of the digital language of computers, video games and the Internet... Those of us who are not born into the digital world but have, at some later points in our lives, become fascinated by and adopted many or most aspects of the new technology, are and always will be compared to them, Digital Immigrants". The terms digital native and immigrant have sparked some meaningful debates due to lack of empirical and theoretical evidence as well as its relation to pedagogical practices. Bennett, Maton and Kervin (2008) likened the digital debate to an 'academic moral panic' where we are unnecessarily making claims for the technology savvy youngsters. Similar sentiments have been raised by Oliver and Goerke (2007) and Kennedy et al (2008). However, this cohort comprises 
'digital adapters' who have adapted the technology and seem to make use of the necessary technology experience in their learning process, especially the ones enrolled in courses that use Moodle (ED Blen and ED Elearn) at USP.

At this point, the author proposes that if these individuals adopt technology in order to mimic or compete with the digital natives then why not call them digital adapter instead? Prensky's comments on digital immigrants "....retaining their foot in the past as in the case of immigrants retaining their accent even though they try to adapt to their environment" as well as his other arguments on this issue do not sit well. The term digital immigrant seems like a 'second class citizen' treatment of the hard working professionals who are readily embracing the new age technology and not learning it from a 'survival techniques' motivation.

'Immigrant' in its essence refers to a group of people who are expected to adapt to the culture of the society they choose to migrate to and it indicates a sense of 'forced' or 'obligatory' action in adopting the ways of this society. On the other hand, the author feels that the term 'adapter' indicates the willingness and enthusiasm in an individual, it makes it a voluntary action, unlike the term 'immigrant' which sounds more like a compromise to the situation. Therefore, the groups of individuals in this study are referred to as 'digital adapters' and not 'digital immigrants'.

This group of digital adapters comprises experienced professionals in education careers, seeking professional development further in their field. The courses that involve an LMS require considerable use of technology, thus access and experience with technology plays a major role. This study indicates the digital adapters have adapted themselves well to study through virtual learning management systems.

The study revealed an important digital status aspect of learners in education courses who are generally over 36 years and mid-career professionals in the field of education, and sometimes expected to be 'less technologically sound'. This study informs the School of Education and USP of digital status and demographics which are an important aspect for consideration if VLEs are used to create an engaging learning environment. In the light of the digital capability and readiness amongst the graduate learners, the academic staff in School of Education and USP at large is also being encouraged to enhance their ICT skills (Sharma, personal communication, 8 February 2010). Since 2010, the School of Education has started offering the professional courses (ED401 and ED402 for GCTT program) fully online to accommodate working professionals (personal observation); these course were originally face to face courses, transformed to blended mode in 2009. The offering of ED401 and 402 fully online is quite significant, considering USP serves not only its thirteen member countries but other, smaller Pacific Island countries too. In the current climate of competition from new universities in Fiji and overseas online universities, the offering of a fully online GCTT program has been a welcome development providing two benefits: increased enrollment revenue for USP, and improved access to education in Pacific Island countries.

Similarly, this study encouraged individual faculty staff in Education to take the initiative to supplement their courses with a Moodle component, such as ED255's summer school December 2010 to January 2011. Another interesting development in the School of Education is that upon discovering the digital status and demographic of the learners, the faculty members were motivated to adapt tools and technology necessary for teaching and learning. While this project may have been a baseline 
survey, it has opened the door to offer online courses responding to the sound technology experience and demographic status of graduate learners in education. Thus this small sample indicates the readiness for e-learning in USP, and further investigation is likelt to strengthen this finding.

\section{Conclusion}

Digital access and experience in this small sample from the Pacific Islands presents an encouraging picture, though it may not necessarily be an accurate representation of all of the Pacific Island countries. The learners in this sample are keen and enthusiastic about use of technology. This unique group was found to be technology savvy; what is even more remarkable is that more than $50 \%$ of the learners belong to a 'post-Windows' era and therefore, should be considered digital adapters. The cohort is mainly middle career professionals who have access to and experience with technology that enables them to adopt e-learning as a suitable and convenient mode. Professional development is desirable in all professions and the professionals in education nowadays feel the need to keep up with the changing needs of society. The majority of the learners being middle aged education professionals and keen on professional development could take courses that are offered through e-learning since it does not impinge upon their work times. An important point emerging from this study is the high level of digital awareness among female learners, with the females outnumbering males in this sample. Very good access to tools and technology and experience with it among female learners indicate that females are capable of adapting to VLEs and are able to study via blended or e-learning modes. The cohort in this study indicates its readiness for e-learning, and may foreshadow the emergence of e-learning as a preferred mode of delivery for postgraduate students.

\section{Limitation and recommendation}

The sample size being small, study needs to be replicated. This study focuses on the learners studying only education and their profession is also that of educator/ administrator in academic institution/ related, it is recommended that study is carried out with learners from different study areas and possibly also different professions.

\section{Acknowledgment}

The author would like to thank the participants in this study for taking out their valuable time to fill in the survey questionnaire as well as the course coordinators for agreeing to provide access to their course work sites and students. The cooperation by the course coordinators is appreciated and acknowledged.

\section{References}

ACER Report (2010). Evaluation of One Laptop Per Child (OLPC) Trial project in the Solomon Islands. Ministry of Education and Human Resources Development, Solomon Islands Government. ACER Final Report on the evaluation of the OLPC program for MEHRD. [viewed 10 Jun 2010, verified 4 May 2011]

http:/ / wiki.laptop.org/images/0/0b/SolomonIslandsOLPCTrialsEvaluationByACER2010.pdf

ADB (Asian Development Bank) (2007). The role of USPNet in capacity development in the South Pacific region. http: / / www.adb.org/ documents / studies / capacity-development-in-thepacific/ USPNet-Capacity-Development.pdf 
Amber, V. (2008). Teaching a new era: Using technology to prepare for the diverse classroom. 31st Annual Proceedings - Selected Research and Development Papers. Presented at the Annual Convention of the Association for Educational Communications and Technology. pp 221224, Orlando, FL.

Baba, T. (1997). Higher education and human resource development in the Pacific. Directions, 19(2). [verified 4 May 2011]

http: / / www.directions.usp.ac.fj/ collect/ direct/index/assoc/D770136.dir/doc.pdf

Bakalevu, S. (2005). Regional perspective on current status and trends of ICT applications in education. In ICT in secondary education in the Pacific region: Status, trends and prospects. Suva: University of the South Pacific.

Bennett, S., Maton, K. \& Kervin, L. (2008). The 'digital natives' debate: A critical review of the evidence. British Journal of Educational Technology, 39(5), 775-786. [viewed 6 Mar 2011] DOI: $10.1111 /$ j.1467-8535.2007.00793.x

Bolabola, C. \& Wah, R. (Eds) (1995). South Pacific women in distance education: Studies from countries of the University of the South Pacific. Suva, Fiji: The University of the South Pacific and The Commonwealth of Learning.

Burnip, L. (2006). ICT mediated study and teachers: Do they have access to the infrastructure? Australasian Journal of Educational Technology, 22(3), 355-374. http: / / www.ascilite.org.au/ajet/ajet22/burnip.html

Cameron, D. \& Anderson, T. (2006). Comparing weblogs to threaded discussion tools in online educational contexts. International Journal of Instructional Technology and Distance Learning, 2(11). http: / / www.itdl.org/Journal/Nov_06/article01.htm

Chief, I. Y. \& Hola, L. (1995). Patterns of study behaviour of the USP Extension students. The University of South Pacific, University Extension.

Hammond, O. W. (2000). Pacific megatrends in education. PREL Briefing Paper. Honolulu: Pacific Resources for Education and Learning. http:/ / www.prel.org/products/Products/Pacificmegatrends.pdf

He, J., Wang, P. \& Li, X. (2008). Issues and best practices of virtual teamwork in online learning environment. 31st Annual Proceedings - Selected Research and Development Papers. Presented at the Annual Convention of the Association for Educational Communications and Technology. pp 92-98, Orlando, FL.

Johanson-Fua, S. (2005). ICT in secondary education in the Pacific: Status, trends and prospects. Regional Workshop on ICT in Education: A Summation.

Kennedy, G. E., Judd, T. S., Churchward, A., Gray, K. \& Krause, K. L. (2008). First year students' experience with technology: Are they really digital natives? Australasian Journal of Educational Technology, 24(1), 108-122. http:/ / www.ascilite.org.au/ajet/ajet24/kennedy.html

Lal, V. (1989). Some suggestions regarding how adults should be taught and their acceptability with adult learners studying through the Fiji Centre of the University of the South Pacific Extension Services. Report of a research project. Extension Service. USP.

Marsh, C. \& Hogan, R. (Eds.) (2005). Distance education the Pacific way: A multi modal teaching approach for South Pacific learners. The International Journal of Learning, 12.

Nabobo-Baba, U. (2002). Computer tigers and coconut trees. In F. Pene, A. M. Taufe'ulungaki, C. Benson \& K. Sanga (Eds.), Tree of opportunity: Re-thinking Pacific education. (pp.36-47). Institute of Education, University of the South Pacific, Suva.

Negroponte, N. (2002). It's not a laptop project. It's an education project. [viewed 19 Sep 2009, verified 4 May 2010] http:/ / laptop.org/en/vision/mission/index.shtml 
Oliver, B. \& Goerke, V. (2007). Australian undergraduates' use and ownership of emerging technologies: Implication and opportunities for creating engaging learning experiences for the Net Generation. Australasian Journal of Educational Technology, 23(2), 171-186. http: / / www.ascilite.org.au/ajet/ajet23/oliver.html

Prasad, B. C. (1988). Organization and drop out rates in distance education: A preliminary study of the Fiji Centre of USP's Extension Services. Directions, 10(2), 146-159. [verified 4 May 2011] http: / / www.directions.usp.ac.fj/ collect/ direct/index/assoc/D769968.dir/doc.pdf

Prensky, M. (2001). Digital natives, digital immigrants. On the Horizon, 9(5). MCB University Press. http:/ / www.marcprensky.com/writing/prensky\%20$\%$ 20digital $\% 20$ natives, $\% 20$ digital $\% 20$ immigrants $\% 20-\% 20$ part1.pdf

Puamau, P. (2005). Rethinking educational platform: A Pacific perspective. Paper presented at the International Conference Redesigning pedagogy: Research, Policy \& Practice, National Institute of Education, Nanyang Technological University, Singapore, 30 May-1 June.

Shank, P. (2005). 5 common fears about teaching online - fact vs. fiction. Online Classroom, 1 October.

Sharma, A. N. (2008). ICT in teacher education: The USP experience. In J. Dorovolomo, C. F. Koya, H. P. Phan, U. Nabobo-Baba \& J. Veramu (Eds), Pacific education: Issues and perspectives (pp 165-179). Suva: University of the South Pacific. [verified 4 May 2011] http: / / sta.uwi.edu/conferences / 09/salises/documents / A\%20Sharma.pdf

Shehab, S. A. J. (2007). Undergraduate learners' perceptions of blended learning and its relationship with some demographic and experiential variables at the Arab Open University - Bahrain Branch. Unpublished Master's Thesis. [verified 4 May 2011; 1.4 MB] http:/ / www.eric.ed.gov:80/ ERICWebPortal/ contentdelivery/ servlet/ ERICServlet?accno=ED500044

Taylor, J. C. (1995). Distance education technologies: The fourth generation. Australasian Journal of Educational Technology, 11(2), 1-7. http:/ / www.ascilite.org.au/ajet/ajet11/taylor.html

Thaman, K. H. (2001). Open and flexible learning for whom? Rethinking distance education. Directions, 23(1). http:/ / www.directions.usp.ac.fj/ collect/direct/index/assoc/D770198.dir/doc.pdf

Tong, T. W. (2004). Free and open source software FOSS. UNDP Asia Pacific Development Information Programme.

Tuimaleali'ifano, E. (1994). Addressing some gender issues in distance education at the University of South Pacific. Open Praxis, 1, 15-18.

Whelan, R. (2007). Elearning in the South Pacific: Current status, challenges \& trends. Survey findings from the Pacific eLearning Observatory. Centre for the Educational Development \& Technology, Pacific eLearning Observatory Project. Draft 21 September. [verified 4 May 2011] http:/ / www.usp.ac.fj/fileadmin/files/schools/dfl/pdsu/pdfs/pelo_survey_full.pdf

\section{Appendix}

\section{Background (click on suitable response)}

Programme of study: Certificate $\square$ Diploma $\square$ Bachelors $\square$ Masters $\square$ Other $\square$
Highest qualification: Certificate $\square$ Diploma $\square$ Bachelors $\square$ Masters $\square$ PhD $\square$
Years in current profession: $<2$ yrs $\square \quad$ 2-5 yrs $\square \quad 5$-10 yrs $\square>10$ yrs $\square$
Gender: $\quad$ Male $\square \quad$ Female $\square$
Age: 18-25yrs $\square \quad$ 26-35yrs $\square \quad$ 36-45yrs $\square \quad 46-55$ yrs $\square>55$ yrs $\square$
Profession $\quad$ Ethnicity




\section{Technology background (click on suitable response)}

How long have you used computers?: $<2$ yrs $\square \quad 2-5$ yrs

How long have you used Internet?: $\quad<2$ yrs $\square \quad 2-5$ yrs

5-10 yrs $\square>10$ yrs $\square$

at work: YES $\square$ NO $\square$

I have Internet access at home: YES $\square$ NO

at work: YES $\square$ NO

Internet connection (check all that apply): Broadband $\square \quad$ Dialup $\square \quad$ Wireless I have a mobile phone: $\quad$ YES $\square$ NO $\square$

3. Application experience (click on suitable response)

$1=$ Least; 2 = Fair; $3=$ Good; $4=$ Very good; $5=$ Excellent

\begin{tabular}{|l|c|c|c|c|c|}
\hline Rate your level of proficiency with: & $\mathbf{1}$ & $\mathbf{2}$ & $\mathbf{3}$ & $\mathbf{4}$ & $\mathbf{5}$ \\
\hline Word processing & $\square$ & $\square$ & $\square$ & $\square$ & $\square$ \\
\hline Spreadsheets & $\square$ & $\square$ & $\square$ & $\square$ & $\square$ \\
\hline Paint, Publisher, etc & $\square$ & $\square$ & $\square$ & $\square$ & $\square$ \\
\hline Email & $\square$ & $\square$ & $\square$ & $\square$ & $\square$ \\
\hline Class Shares & $\square$ & $\square$ & $\square$ & $\square$ & $\square$ \\
\hline Moodle, Nicenet, WebCT or other LMS & $\square$ & $\square$ & $\square$ & $\square$ & $\square$ \\
\hline Online library searches & $\square$ & $\square$ & $\square$ & $\square$ & $\square$ \\
\hline Search engines e.g. Google, Yahoo, online dictionary, etc. & $\square$ & $\square$ & $\square$ & $\square$ & $\square$ \\
\hline Online services e.g. registration, pay fees etc. & $\square$ & $\square$ & $\square$ & $\square$ \\
\hline Bebo, Facebook, Twitter, etc. & $\square$ & $\square$ & $\square$ & $\square$ & $\square$ \\
\hline Yahoo Messenger, MSN, Gtalk, Skype, etc. & $\square$ & $\square$ & $\square$ & $\square$ \\
\hline Blogs & $\square$ & $\square$ & $\square$ & $\square$ \\
\hline
\end{tabular}

Authors: Shikha Raturi (corresponding author) has taught chemistry for nearly 20 years, the first 10 years dedicated to senior high school chemistry and the next 10 years to undergraduate chemistry in PNG University of Technology and the University of the South Pacific. She takes a keen interest in the use of technology to enhance learning and teaching experiences. A part of this paper was her Master's research project in education in 2009 at USP. Currently she lives in Suva, Fiji, freelancing as a volunteer and education consultant. Email: shikhanr@gmail.com

Dr Robert Hogan worked as an Associate Professor in the School of Education, Faculty of Arts and Law, University of the South Pacific, Suva, Fiji until March 2011.

Konai Helu Thaman is Professor of Education and UNESCO Chair in Teacher Education and Culture in the School of Education, Faculty of Arts and Law, University of the South Pacific, Suva, Fiji. Email: thaman_k@usp.ac.fj

Web: http:/ / www.usp.ac.fj/ unescochair/

Please cite as: Raturi, S., Hogan, R. \& Thaman, K. H. (2011). Learners' access to tools and experience with technology at the University of the South Pacific: Readiness for elearning. Australasian Journal of Educational Technology, 27(3), 411-427.

http: / / www.ascilite.org.au/ajet/ajet27 / raturi.html 